(n)

\title{
Competitive pressure by territorials promotes the utilization of unusual food source by subordinate ants in temperate European woodlands
}

Katalin Erős, István Maák, Bálint Markó, Hanna Babik, Piotr Ślipiński, Roxana Nicoară \& Wojciech Czechowski

To cite this article: Katalin Erős, István Maák, Bálint Markó, Hanna Babik, Piotr Ślipiński, Roxana Nicoară \& Wojciech Czechowski (2020): Competitive pressure by territorials promotes the utilization of unusual food source by subordinate ants in temperate European woodlands, Ethology Ecology \& Evolution, DOI: 10.1080/03949370.2020.1753116

To link to this article: https://doi.org/10.1080/03949370.2020.1753116

Published online: 07 May 2020.

Submit your article to this journal

山 Article views: 9

Q View related articles 두

View Crossmark data $₫$ 


\title{
Competitive pressure by territorials promotes the utilization of unusual food source by subordinate ants in temperate European woodlands
}

\author{
Katalin Erös ${ }^{1}$, István MaÁK (iD ${ }^{2, *}$, Bálint Markó ${ }^{1}$, Hanna BabiK $^{2}$, Piotr Ślipiński ${ }^{2}$, \\ ROXANA NiCOARA ${ }^{3}$ and WOJCIECH CZECHOWSKI ${ }^{2}$ \\ ${ }^{1}$ Hungarian Department of Biology and Ecology, Babeş-Bolyai University, Cluj-Napoca, \\ Romania \\ ${ }^{2}$ Museum and Institute of Zoology, Polish Academy of Sciences, Warsaw, Poland \\ ${ }^{3}$ Department of Ecology, Taxonomy and Nature Conservation, Institute of Biology \\ Bucharest, Romanian Academy, Bucharest, Romania
}

Received 13 December 2019, accepted 11 March 2020

\begin{abstract}
In the presence of territorial dominant ant species, lower-ranked ants change their foraging strategy by shifting their activity in time and space and by switching to suboptimal food sources. Although important for many insect species, pollen is a rarely used food source by ants. Occasional pollen consumption was demonstrated only in a handful of ant species that are mainly lower-ranked in the competitive hierarchy. We hypothesized that the consumption of pollen by subordinate ants might be enhanced by competitive pressure exerted by dominant species. In the frame of the current study, we assessed the food preference of ant species within a supercolony of the territorial wood ant Formica polyctena by offering them pollen and animal protein baits. Subordinate ant species, especially Myrmica ants, exploited both pollen and animal protein, while F. polyctena foraged only for animal protein. The Myrmica ants exploited pollen sources more intensively on plots where $F$. polyctena dominated animal protein baits, thus interspecific competition was stronger. As suggested by our study, under suboptimal conditions, where food availability is hindered, e.g. by the presence of superior competitors, pollen can, indeed, be used as a food source by subordinate ants.
\end{abstract}

KEY WORDS: food preference, foraging, Formica polyctena, interspecific competition, Myrmica, Temnothorax.

\section{INTRODUCTION}

In the ant communities of temperate climate, species are hierarchically arranged, and the hierarchy consists of a few main levels of competition (see Cerdá et al. 2013 for a review). Submissive species defend only their nest territory,

\footnotetext{
"Corresponding author: István Maák, Museum and Institute of Zoology, Polish Academy of Sciences, Ul. Wilcza 64, Warsaw 00-679, Poland (E-mail: bikmakk@gmail.com).
} 
subdominant (encounter) species the food source as well, whereas dominant (territorial) species defend their whole foraging area (Pisarski \& Vepsäläinen 1989). When cooccurring with territorials, subordinate species need to adapt to the strong ecological pressure exerted by the dominants. They can shift their activity in space (e.g. from the litter surface to within the litter) or in time (e.g. from daytime to evening), or they adjust their resource utilization strategy (e.g. selecting for smaller food pieces or using less rewarding sources) (Savolainen \& Vepsäläinen 1989; Savolainen et al. 1989; Gallé 1990; Vepsäläinen \& Savolainen 1990; Savolainen 1991; Punttila et al. 1996; Czechowski \& Vepsäläinen 2001; Czechowski \& Markó 2006; Czechowski et al. 2013).

Pollen could be such an alternative resource available everywhere in the temperate climate. It is rich in nutrients, with protein levels ranging from $2.5 \%$ to $60 \%$, but it also contains various amino acids, lipids, carbohydrates, and vitamins (Roulston \& Cane 2000). While it is common in the diets of many insect groups (Wäckers et al. 2005), pollen is rarely exploited by ants (Baroni-Urbani \& de Andrade 1997; Creighton 1963, 1967; Creighton \& Nutting 1965; Wang \& Tang 1994; Czechowski et al. 2008, 2011). For long time ants were considered to be only harmful (e.g., they consume floral nectar, deter true pollinators, cause damage to flowers) or neutral at best for pollination (see Galen \& Butchart 2003; Ness 2006; de Vega et al. 2009). In addition, it is known that some plants have evolved traits to keep ants away by employing repellent scents or developed morphological features that block ants from accessing nectar (e.g. Junker et al. 2007; Junker \& Blüthgen 2008; Willmer et al. 2009; Ballantyne \& Willmer 2012). In recent years, though, an increasing amount of data is available on ant pollination (see Fowler \& Whitford 1982; Peakall et al. 1991; Gómez et al. 1996; Puterbaugh 1998; de Vega \& Gómez 2014; de Vega et al. 2014). Ants can be involved in pollination also indirectly by keeping away less efficient (smaller) pollinators thus letting more efficient (larger) ones engage (Rodríguez-Girones et al. 2013).

On the other hand, only a few ant species are known to be specialized in pollenivory (Creighton 1963, 1967), while sporadic, opportunistic pollen consumption by ants is known in a handful of tropical (Wang \& Tang 1994; Cembrowski et al. 2015) and some temperate North-Palaearctic species (Czechowski et al. 2008, 2011). Czechowski et al. (2011) already hypothesized that in Northern temperate areas occasional pollenivory in ants could be promoted by seasonal food shortages caused by increasing competitive pressure from the part of territorials, as, e.g. wood ant species (subgenus Formica s. str.). In the frame of the present study, we tested whether variations in the presence and abundance of a territorial ant species within its polydomous system could indeed drive subordinate species to utilize pollen more frequently. A large multi-nest system of the wood ant Formica polyctena offered the suitable natural setup to test this hypothesis experimentally.

\section{MATERIALS AND METHODS}

Study species, site, and experimental setups

The wood ant $F$. polyctena is a widespread North-Palaearctic territorial species. Its colonies are usually highly polygynous, and owing to that, they tend to form competitively superior multinest systems, often containing several hundred nests (so-called supercolonies) and covering large expanses of forest. The subject of the study was a supercolony of $F$. polyctena located on the Mt

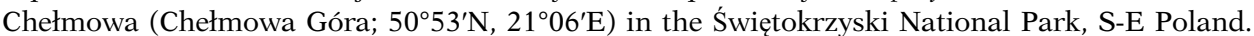
The supercolony consists of ca 500 nests and stretches through all main local forest associations: 
the fertile Carpathian beech forest (Dentario glandulosae-Fagetum), the subcontinental linden-oak -hornbeam forest (Tilio-Carpinetum), and the continental mixed pine forest (Querco roborisPinetum) (see Matuszkiewicz 2007). Myrmecofauna of this region was previously studied by Rzeszowski et al. (2013).

The study site was located in the mixed pine forest area, and it included part of the F. polyctena supercolony with more than 40 nests (see fig. 9 in Rzeszowski et al. 2013). We selected four areas randomly within the studied part of the supercolony. In each area 15 randomly selected $20 \times 20 \mathrm{~cm}$ observation plots were set up $(\mathrm{N}=60)$ on 26 and 27 August 2013. The experiment was carried out in the peak season and period of the species activity; thus, seasonal variations in food availability or colony life cycle should not influence the outcome. The plots were located at a minimum of $10 \mathrm{~m}$ from a margin of any $F$. polyctena mound. We placed one item of bait in the middle of each plot. Two observation series were carried out: one with pollen bait and then one with tuna as a source of animal protein on the following day. Honeybee-collected mixed pollen pellets ( $2 \mathrm{~g}$, without any additives, purchased from apiary) were placed on $5 \mathrm{~cm}$ diameter round red plastic cards on bamboo sticks at flower height $(\sim 15 \mathrm{~cm})$. On the following day, tuna flakes were put out in the same manner as pollen pellets. Tuna flakes are conventionally used as experimental animal protein bait for ants (e.g. Savolainen \& Vepsäläinen 1988; Markó \& Czechowski 2012; Czechowski et al. 2013). Since they are known to attract ants, they were put out 1 day after the pollen bait had been put out in order not to influence the exploitation pattern observed on the pollen bait. Thus, they served to confirm or dismiss the hypothesis that the exploitation pattern of pollen sources reflects general resource utilization patterns. Observations were carried out between 4:30 and $6 \mathrm{pm}$ each day. We recorded the number and species of ants within the plots on the ground and those at the baits, separately. Data originating from plots were considered to reflect the general epigaeic activity of ants including also recruitment and guarding, while data coming from bait items were considered to reflect activities strictly related to the food source exploitation. Each plot and bait was verified 4 times each day, and each observation lasted $1 \mathrm{~min}$, separated from the next by $30 \mathrm{~min}$ in order not to disturb the bait exploitation process. Each item of bait was put out at least $15 \mathrm{~min}$ prior to the first observation. Subordinate ant species could be identified only to genera under field conditions in order to avoid any disturbance.

\section{Data management}

Differences in the abundance of ant species in different plots were tested using Generalized Linear Mixed Model approach (GLMM, negative binomial, maximum likelihood approximation, $\mathrm{N}=480$ ), separately. Plot type (based on the type of bait placed inside) was introduced as a factor. In the case of subordinate species, the abundance of the other species and its interaction with plot type were also included as covariates.

The differences in the frequency of subordinates within different plots and at different baits in the absence and in the presence of the territorial species were analyzed using Fisher's exact test, separately for every subordinate species.

Differences in the abundance of Myrmica individuals at different baits were compared using GLMM approach (GLMM, Poisson, maximum likelihood, $\mathrm{N}=480$ ). Similar analyses could not be performed for the other two species, since they were not present at both bait types in sufficient numbers (see Results). Thus, in Myrmica, bait type was introduced as a factor, the abundance of $F$. polyctena individuals at baits and the individuals of both species ( $F$. polyctena and Temnothorax sp.) in plots surrounding the baits as covariates. We hypothesized that pollen consumption in Myrmica might be driven by high competitive pressure by F. polyctena. In order to test this, we performed a separate GLMM analysis (negative binomial, maximum likelihood, $\mathrm{N}=240$ ), where the abundance of Myrmica at pollen was the output variable, whereas the presence of $F$. polyctena in plots when tuna was introduced was the input variable, as a proxy of $F$. polyctena's interest in a specific plot when something worth exploiting is present. 
Changes in the abundance of $F$. polyctena at tuna baits were also analyzed (GLMM, negative binomial, maximum likelihood, $\mathrm{N}=240$ ). The abundance of Myrmica individuals at baits was introduced as a covariate, but also the abundance of Myrmica and F. polyctena individuals in the plots surrounding the baits. Since Temnothorax spp. was present in a very low number and also a low frequency at tuna baits (see Results), a similar analysis could not be performed in its case.

In all of the above models, the time sequence of observations and the plot/bait IDs were introduced as random factors in order to handle dependencies. The best models were selected with the help of automated model selection. All statistical analysis was carried out using the R 3.1.3 statistical environment (R Core Team 2018). GLMMs were performed using glmer and glmer.nb functions in lme4 package (Bates et al. 2014), while automated model selection with the help of the dredge function in the MuMIn package (Barton 2013).

\section{RESULTS}

Ants in the observation plots

Three ant taxa were recorded within the plots and at the baits: F. polyctena was the most abundant, but ants of the genera Myrmica and Temnothorax were also quite frequent [according to Rzeszowski et al. (2013) data they were, most probably, $M$. ruginodis and $T$. crassispinus, respectively].

The abundance of the territorial $F$. polyctena was significantly higher in plots with tuna than with pollen (GLMM z $=12.06, \mathrm{~N}=480, P<0.001$; Fig. 1 ). The best GLMM model explaining the abundance of the Myrmica spp. in the plots included the bait type and the abundance of $F$. polyctena and Temnothorax spp. individuals in the plots. The abundance of Myrmica spp. did not differ significantly between plots with different baits $(\mathrm{z}=0.55, P=0.58)$, while Formica polyctena had a negative effect on the abundance of Myrmica spp. $(\mathrm{z}=-2.09, P<0.05)$, but on Temnothorax spp. did not

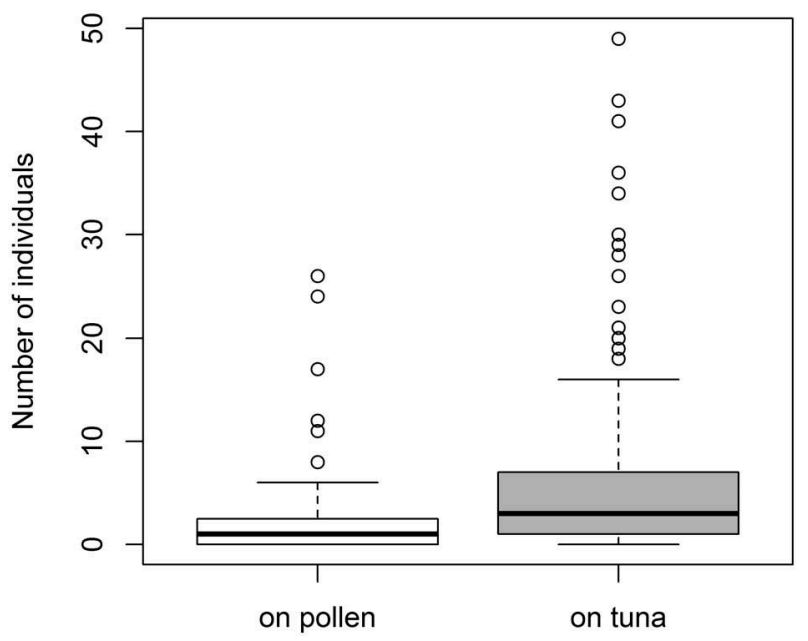

Fig. 1. - Abundance of F. polyctena within observation plots at baits of different types (medians, quartiles, min-max values, and outliers). 


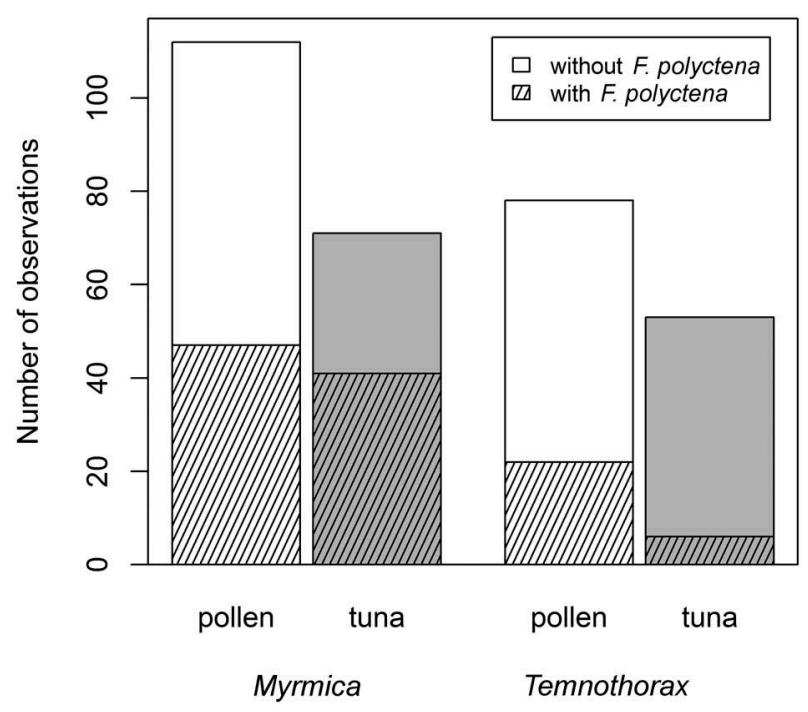

Fig. 2. - Occurrence of subordinates within observation plots at baits of different types in the absence and in the presence of $F$. polyctena.

$(\mathrm{z}=0.36, P=0.72)$. The similar model in Temnothorax spp. included only the bait type, and its abundance was significantly lower in plots with tuna $(\mathrm{z}=-3.39, P<0.001)$.

In the presence of $F$. polyctena, both subordinates occurred significantly more frequently in plots with pollen baits (Fisher's exact test $P<0.001, \mathrm{~N}=4$; Fig. 2).

\section{Exploitation of baits}

Formica polyctena individuals were heavily exploiting tuna baits, but none was recorded exploiting pollen, while Temnothorax individuals were rarely seen exploiting any of the baits: a single individual was recorded at pollen and three at tuna. Myrmica spp. was the only one to exploit both bait types.

The best model concerning the abundance of Myrmica individuals at both bait types contained the bait type, the abundance of $F$. polyctena at baits and those of Myrmica spp. in the plots. The abundance of Myrmica spp. was lower at tuna baits (GLMM z $=-1.99, \mathrm{~N}=480, P<0.05$ ). The abundance of Myrmica spp. in the plots surrounding the baits had a significant positive effect on the number of ants at baits $(\mathrm{z}=4.6, P<0.001)$, whereas the abundance of $F$. polyctena at baits had no significant effect $(\mathrm{z}=1.58, P=0.11)$. At baits with pollen, the abundance of Myrmica spp. was positively affected by the presence of the $F$. polyctena recorded at tuna at the same plots (GLMM z $=3.53, \mathrm{~N}=240, P<0.001)$.

On the other hand, the abundance of $F$. polyctena at baits with tuna was affected positively by the abundance of $F$. polyctena in the plots surrounding the baits $(\mathrm{z}=3.49$, $P<0.001)$, whereas the abundance of Myrmica spp. at baits had no effect ( $\mathrm{z}=-1.7$, $P=0.09)$. Other variables were not included. 


\section{DISCUSSION}

We examined the effect of the polydomous and territorial $F$. polyctena, which represents the top dominant species of the interspecific competitive ant hierarchy in boreal and temperate Eurasia, on the utilization of alternative food sources, pollen in this specific case, by subordinate ant species. Our main result shows that subordinate species, mostly Myrmica spp., in the presence of stronger competitors (wood ants) forage on and recruit to pollen.

The tendency of subordinates to adapt to the presence of dominants by changing their foraging strategies, including switching to less rewarding food sources, has been documented in many different ant species (Vepsäläinen \& Pisarski 1982; Savolainen \& Vepsäläinen 1988; Vepsäläinen et al.1989; Savolainen 1991; Markó \& Czechowski 2012; Czechowski et al. 2013; Markó et al. 2013). One such possible alternative source could be pollen, which has a high nutritional value (Roulston \& Cane 2000), but ants often avoid it, possibly because of repellents produced by plants (Willmer \& Stone 1997; Ghazoul 2001; Raine et al. 2002; Wagner \& Kay 2002; Nicklen \& Wagner 2006; Junker et al. 2007; Junker \& Blüthgen 2008; Willmer et al. 2009). Based on our findings, subordinate ant species, such as Myrmica spp. nesting within the territories of dominant ants, indeed tend to consume pollen, which is usually avoided or at least markedly less utilized by the stronger competitor. However, under some conditions also these species can use pollen (Czechowski \& Vepsäläinen 2009; I. Maák pers. observation). Some studies on worker ant crop content demonstrated that several Palaearctic ant species, mainly those lower-ranked in the competitive hierarchy, are occasional pollen-consumers, including three Myrmica species: M. schencki, M. rubra and M. ruginodis (Czechowski et al. 2008, 2011). Moreover, pollen was found in the alimentary canal of larvae of 15 ant species from tropical forests (Cembrowski et al. 2015).

The negative effect of $F$. polyctena on subordinates is clearly revealed by its negative impact on the presence of Myrmica foragers at tuna. In this case, several other field studies demonstrate the decisive restrictive effects of territorial wood ants on co-occurring subordinate ant species (Vepsäläinen \& Pisarski 1982; Savolainen \& Vepsäläinen 1988; Vepsäläinen et al.1989; Savolainen 1991; Markó \& Czechowski 2012; Czechowski et al. 2013; Markó et al. 2013). In addition, the fact that the presence of $F$. polyctena had a negative effect on the abundance of the Myrmica species, but influenced positively their abundance at pollen baits implies that ants of the genus Myrmica in the presence of the dominant tend to switch to less rewarding food sources. Savolainen and Vepsäläinen (1989) previously demonstrated that Myrmica species shift their activity in space and time in the presence of $F$. polyctena. Our findings complete this picture.

It was already proven that several Palaearctic ant species occasionally consume pollen. However, our study demonstrates that the consumption of pollen in ants can be much more frequent than was originally thought, and competition can be one of the factors that promote ants to overcome the repellents produced by plants. Thus, pollen may constitute an important food source in communities where competition is fierce, and ant repellents produced by plants may play a more significant role for plants in protecting themselves against ants in ant communities with highly competitive territorials. The differential production of such repellent agents in the same plant species but under different circumstances with regards to the ant populations could be the subject of further studies. 


\section{ACKNOWLEDGEMENTS}

We are grateful for the helpful comments of Xim Cerdá, which greatly improved the quality of this paper. The study was carried out within the frame of scientific cooperation between the Polish Academy of Sciences and the Romanian Academy. During manuscript preparation, Bálint Markó's work was supported by the Bolyai János scholarship of the Hungarian Academy of Sciences.

\section{DISCLOSURE STATEMENT}

No potential conflict of interest was reported by the authors.

\section{FUNDING}

This work was supported by the Magyar Tudományos Akadémia [Bolyai János].

\section{AUTHOR CONTRIBUTION}

K. Erős, B. Markó and W. Czechowski designed the experiment, K. Erős, B. Markó, I. Maák, H. Babik, P. Ślipiński and R. Nicoară carried out the field experiments and the data collection, K. Erős, I. Maák and B. Markó carried out the data analysis. K. Erös, I. Maák, B. Markó, and W. Czechowski wrote the manuscript, and all authors participated in the revision of the final version.

\section{ORCID}

István Maák (ib) http://orcid.org/0000-0002-0999-4916

\section{REFERENCES}

Ballantyne G, Willmer P. 2012. Nectar theft and floral ant-repellence: a link between nectar volume and ant-repellent traits. PLoS ONE. 7:e43869. doi:10.1371/journal.pone.0043869

Baroni-Urbani C, de Andrade ML. 1997. Pollen eating, storing, and spitting by ants. Naturwissenschaften. 84:256-258. doi:10.1007/s001140050392

Bartoń K 2013. MuMIn: multi-model inference. R package version 1. 9.13. Available from: http:// CRAN.R-project.org/package $1 / 4$ MuMIn [Accessed 09 Oct 2019].

Bates D, Maechler M, Bolker B, Walker S. 2014. 1me4: linear mixed-effects models using Eigen and S4. R package version 1.1-7. Available from: http://CRAN.R-project.org/package=lme4 [Accessed 10 Oct 2019].

Cembrowski AR, Reurink G, Hernandez LA, Sanders JG, Youngerman E, Frederickson ME. 2015. Sporadic pollen consumption among tropical ants. Insect Soc. 62:1-4. doi:10.1007/s00040-015-0402-x

Cerdá X, Arnan X, Retana J. 2013. Is competition a significant hallmark of ant (Hymenoptera: Formicidae) ecology? Myrmecol News. 18:131-147.

Creighton WS. 1963. Further studies on the habits of Cryptocerus texanus Santschi (Hymenoptera: Formicidae). Psyche. 70:133-143. doi:10.1155/1963/78162 
Creighton WS. 1967. Studies on free colonies of Cryptocerus texanus Santschi (Hymenoptera: Formicidae). Psyche. 74:34-41. doi:10.1155/1967/54234

Creighton WS, Nutting WL. 1965. The habits and distribution of Cryptocerus rohweri Wheeler (Hymenoptera: Formicidae). Psyche. 72:59-64. doi:10.1155/1965/79407

Czechowski W, Markó B. 2006. Uncomfortable protection: Formica polyctena Först. shelters Formica fusca L. from Formica sanguinea Latr. (Hymenoptera: Formicidae). Ann Zool. 56:539-548.

Czechowski W, Markó B, Erös K, Csata E. 2011. Pollenivory in ants (Hymenoptera: Formicidae) - much more common than it was thought. Ann Zool. 61:519-525. doi:10.3161/000345411X603364

Czechowski W, Markó B, Radchenko A. 2008. Rubbish dumps reveal the diet of ant colonies: Myrmica schencki Em. and Myrmica rubra L. (Hymenoptera: Formicidae) as facultative pollen eaters. Pol J Ecol. 56:737-741.

Czechowski W, Markó B, Radchenko A, Ślipiński P. 2013. Long-term partitioning of space between two territorial species of ants (Hymenoptera: Formicidae) and their effect on subordinate species. Eur J Entomol. 110:327-337. doi:10.14411/eje.2013.046

Czechowski W, Vepsäläinen K. 2001. Formica rufa L. protects indirectly $F$. fusca L. against raids of F. sanguinea Latr. (Hymenoptera: Formicidae). Ann Zool. 51:267-273.

Czechowski W, Vepsäläinen K. 2009. Territory size of wood ants (Hymenoptera: Formicidae): A search for limits of existence of Formica polyctena Först., an inherently polygynic and polycalic species. Ann Zool. 59:179-187. doi:10.3161/000345409X463994

de Vega C, Arista M, Ortiz PL, Herrera CH, Talavera S. 2009. The ant-pollination system of Cytinus hypocistis (Cytinaceae), a Mediterranean root holoparasite. Ann Bot. 103:1065-1075. doi:10.1093/aob/mcp049

de Vega C, Gómez JM. 2014. Polinización por hormigas: conceptos, evidencias y futuras direcciones [Pollination by ants: concepts, evidences and future directions.]. Ecosistemas. 23:48-57. doi:10.7818/ECOS.2014.23-3.07. Spanish.

de Vega C, Herrera CM, Dötterl S. 2014. Floral volatiles play a key role in specialized ant pollination. Perspect Plant Ecol. 16:32-42. doi:10.1016/j.ppees.2013.11.002

Fowler HG, Whitford WG. 1982. Floral visitation by Chihuahuan desert ants. J Nat Hist. 16:879-881. doi:10.1080/00222938200770701

Galen C, Butchart B. 2003. Ants in your plants: effects of nectar-thieves on pollen fertility and seed-siring capacity in the alpine wildflower, Polemonium viscosum. Oikos. 101 (3):521-528. doi:10.1034/j.1600-0706.2003.12144.x

Gallé L. 1990. Assembly of sand-dune forest ant communities. Memorabilia Zool. 44:1-6.

Ghazoul J. 2001. Can floral repellents pre-empt potential ant-plant conflicts? Ecol Lett. 4 (4):295-299. doi:10.1046/j.1461-0248.2001.00229.x

Gómez JM, Zamora R, Hódar JA, García D. 1996. Experimental study of pollination by ants in Mediterranean high mountain and arid habitats. Oecologia. 105(2):236-242. doi:10.1007/ BF00328552

Junker RR, Blüthgen N. 2008. Floral scents repel potentially nectar-thieving ants. Evol Ecol Res. 10:295-308.

Junker RR, Chung AYC, Blüthgen N. 2007. Interaction between flowers, ants and pollinators: additional evidence for floral repellence against ants. Ecol Res. 22(4):665-670. doi:10.1007/ s11284-006-0306-3

Markó B, Czechowski W. 2012. Space use, foraging success and competitive relationships in Formica cinerea (Hymenoptera Formicidae) on sand dunes in southern Finland. Ethol Ecol Evol. 24(2):149-164. doi:10.1080/03949370.2011.634438

Markó B, Czechowski W, Radchenko A. 2013. Combining competition with predation: drastic effect of Lasius fuliginosus (Latr.) on subordinate ant species at the northern limit of its distribution. Ann Zool. 63(1):107-111. doi:10.3161/000345413X666156

Matuszkiewicz W. 2007. Przewodnik do oznaczania zbiorowisk roślinnych Polski [Guide to the identification of Polish plant communities]. Warszawa: Państwowe Wydawnictwo Naukowe. Polish. 
Ness JH. 2006. A mutualism's indirect costs: the most aggressive plant bodyguards also deter pollinators. Oikos. 113(3):506-514. doi:10.1111/j.2006.0030-1299.14143.x

Nicklen EF, Wagner D. 2006. Conflict resolution in an ant-plant interaction: Acacia constricta traits reduce ant costs to reproduction. Oecologia. 148(1):81-87. doi:10.1007/s00442-0060359-6

Peakall R, Handel SN, Beattie AJ. 1991. The evidence for, and importance of, ant pollination. In: Huxley CR, Cutler D, editors. Ant-plant interaction. Oxford: Oxford University Press; p. $421-429$.

Pisarski B, Vepsäläinen K. 1989. Competition hierarchies in ant communities (Hymenoptera, Formicidae). Ann Zool. 42:321-329.

Punttila P, Haila Y, Tukia H. 1996. Ant communities in taiga clearcuts: habitat effects and species interactions. Ecography. 19(1):16-28. doi:10.1111/j.1600-0587.1996.tb00151.x

Puterbaugh MN. 1998. The roles of ants as flower visitors: experimental analysis in three alpine plant species. Oikos. 83(1):36-46. doi:10.2307/3546544

R Core Team. 2018. R: A language and environment for statistical computing. Vienna (Austria): R Foundation for Statistical Computing. Available from: http://www.R-project.org/ [Accessed 09 Oct 2019].

Raine NE, Willmer PG, Stone GN. 2002. Spatial structuring and floral avoidance behaviour prevent ant-pollinator conflict in a Mexican ant-acacia. Ecology. 83:3086-3096.

Rodríguez-Girones MA, Gonzalvez FG, Llandres AL, Corlett RT, Santamaría L, Aizen M. 2013. Possible role of weaver ants, Oecophylla smaragdina, in shaping plant-pollinator interactions in South-East Asia. J Ecol. 101(4):1000-1006. doi:10.1111/1365-2745.12100

Roulston TH, Cane JH. 2000. Pollen nutritional content and digestibility for animals. Plant Syst Evol. 222(1-4):187-209. doi:10.1007/BF00984102

Rzeszowski K, Babik H, Czechowski W, Markó B. 2013. Ants (Hymenoptera: Formicidae) of Chełmowa Góra in the Świętokrzyski National Park. Fragmenta Faunistica. 56(1):17-24. doi:10.3161/00159301FF2013.56.1.001

Savolainen R. 1991. Interference by wood ant influences size selection and retrieval rate of prey by Formica fusca. Behav Ecol Sociobiol. 28(1):1-7. doi:10.1007/BF00172132

Savolainen R, Vepsäläinen K. 1988. A competition hierarchy among boreal ants: impact on resource partitioning and community structure. Oikos. 51(2):135-155. doi:10.2307/ 3565636

Savolainen R, Vepsäläinen K. 1989. Niche differentiation of ant species within territories of the wood ant Formica polyctena. Oikos. 56(1):3-16. doi:10.2307/3566082

Savolainen R, Vepsäläinen K, Wuorenrinne H. 1989. Ant assemblages in the taiga biome: testing the role of territorial wood ants. Oecologia. 81(4):481-486. doi:10.1007/BF00378955

Vepsäläinen K, Pisarski B. 1982. Assembly of island ant communities. Ann Zool Fenn. 19:327-335.

Vepsäläinen K, Savolainen R. 1990. The effect of interference by formicine ants on the foraging of Myrmica. J Anim Ecol. 59(2):643-654. doi:10.2307/4886

Wäckers FL, van Rijn PCJ, Bruin J. 2005. Plant-provided food for carnivorous insects: a protective mutualism and its applications. Cambridge: Cambridge University Press.

Wagner D, Kay A. 2002. Do extrafloral nectaries distract ants from visiting flowers? An experimental test of an overlooked hypothesis. Evol Ecol Res. 4:293-305.

Wang JF, Tang J. 1994. Food abundance and foraging patterns of natural colonies of Polyrhachis vicina Roger (Hymenoptera: Formicidae). Insect Soc. 41(2):141-151. doi:10.1007/ BF01240474

Willmer PG, Nuttman CV, Raine NE, Stone GN, Pattrick JG, Henson K, Stillman P, McIlroy L, Potts SG, Knudsen JT. 2009. Floral volatiles controlling ant behaviour. Funct Ecol. 23(5):888-900. doi:10.1111/j.1365-2435.2009.01632.x

Willmer PG, Stone GN. 1997. How aggressive ant-guards assist seed-set in Acacia flowers. Nature. 388(6638):165-167. doi:10.1038/40610 